\title{
Probable Global Transcription Activator
} SNF2L2

National Cancer Institute

\section{Source}

National Cancer Institute. Probable Global Transcription Activator SNF2 L2. NCI

Thesaurus. Code C19846.

Probable global transcription activator SNF2L2 (1590 aa, 181 kDa) is encoded by the human SMARCA2 gene. This protein is involved in the modulation of hormone receptor transcription factor activity. 